\title{
Evaluation of Carica papaya Leaf Extracts for their Efficacy on Control of Bacterial Wilt of Tomato caused by Ralstonia solanacearum
}

\author{
K. Narasimha Murthy ${ }^{1}$, K. Soumya ${ }^{3 *}$, C. Srinivas ${ }^{2}$ and S.R. Niranjana ${ }^{1}$ \\ ${ }^{1}$ Department of Studies in Biotechnology, University of Mysore, Manasagangotri, \\ Mysore -570 006, Karnataka, India \\ ${ }^{2}$ Department of Microbiology and Biotechnology, Jnanabharathi Campus, Bangalore \\ University, Bangalore- 560 056, India \\ ${ }^{3}$ Department of Microbiology, Field Marshal K. M. Cariappa College, A Constituent College \\ of Mangalore University, Madikeri - 571201, Karnataka, India \\ *Corresponding author
}

\section{A B S T R A C T}

\begin{tabular}{|l|}
\hline Ke y w o r d s \\
Carica papaya, \\
Phytochemicals, \\
Minimum inhibitory \\
concentrations, \\
Ralstonia \\
solanacearum, \\
Plant growth \\
promotion, Tomato \\
yield \\
\hline Article Info \\
\hline $\begin{array}{l}\text { Accepted: } \\
\text { 04 February } 2019 \\
\text { Available Online: } \\
\text { 10 March } 2019\end{array}$ \\
\hline
\end{tabular}

\section{Introduction}

Plant diseases caused by different fungal and bacterial pathogens are the major constraints of tomato production (Jones et al., 1991). Bacterial wilt caused by Ralstonia solanacearum is a destructive disease in the production of tomatoes (Ji et al., 2005). This
Management of bacterial wilt is very difficult as there are no efficient curative chemicals. Carica papaya leaf extract was evaluated their antimicrobial activity against Ralstonia solanacearum. The zone of inhibitions showed against ten $R$. solanacearum at range of $5.96 \mathrm{~mm}$ to $15 \mathrm{~mm}$ of different solvent extracts like aqueous, ethanol, ethyl acetate, hexane, and chloroform. The MIC of methanol at $512 \mu \mathrm{g} / \mathrm{ml}$, ethanol at $2048 \mu \mathrm{g} / \mathrm{ml}$, ethyl acetate at $1024 \mu \mathrm{g} / \mathrm{ml}$, hexane at 1024 $\mu \mathrm{g} / \mathrm{ml}$, chloroform at $1024 \mu \mathrm{g} / \mathrm{ml}$, aqueous at $2048 \mu \mathrm{g} / \mathrm{ml}$ and streptomycin at $<8$ $\mu \mathrm{g} / \mathrm{ml}$. The seed treatment with $C$. papaya leaf extracts increased the seed germination and vigor index (1218.61) when compared to control (1152.69). Under greenhouse conditions plants treatments with $C$. papaya extracts were increased plant growth and decreased wilt incidence about 42.29-52.14\%. In field study the reduction of wilt by $C$. papaya leaf extracts at $100 \mathrm{mg} / \mathrm{ml}$ concentration. C. papaya leaf extracts increased the yield by $15.08 \%(1.3 \mathrm{t} / \mathrm{ha})$ and decreased the wilt incidence by $52.14 \%$. 
vary widely 0 to $91 \%$ (Elphinstone, 2005) and 10.8 to $90.6 \%$ depending on the environmental conditions (Kishun, 1987). Bacterial Wilt poses a continuous danger to tomato in Karnataka, Kerala, Maharashtra, Odisha, Jharkhand, Goa, West Bengal, Himachal Pradesh, Jammu and Kashmir, Uttarakhand and Northeastern states in India (Singh et al., 2016). R. solanacearum inhabits the vascular tissue of its host plants. The $R$. solanacearum in general invades host roots from primary sources of inoculum through soil, wounds or natural openings at the site of secondary roots emerge (Hayward 1991; Pradhanang et al., 2005). R. solanacearum colonizes in the root cortex and vascular tissues and finally enters the xylem vessels and spreads areal parts of the host. After the pathogen colonized the xylem, a large number of bacterial cells and blocking the water movement into upper parts of the plant. Affected plants suffer chlorosis, stunting, wilting, and usually die rapidly.

Bacterial wilt disease is most difficult to control and the effectiveness of present strategies for control of this disease is inadequate. No conventional bactericides are known to provide successful management of this $R$. solanacearum pathogen (Ahmed et al., 2000; Williamson et al., 2002). Management in chemical pesticides is usually considered as the most efficient and fastest approach for phytopathogens control however, there is no effective chemical product is available for control of bacterial wilt. In vitro and in vivo investigations by some investigators have established the potential antimicrobials from some plant species (El-Ariqi, 2005). In a challenge to change this situation, some alternative techniques of control have been adopted. Within this situation is the usage of plant extracts which are natural sources of antimicrobial compounds, regarded as environmental safe and biodegradation by natural soil microorganisms; there is no any health residual or environmental problems at any type of concentration of plant extracts used but effective against plant pathogens (Shivpuri et al., 1997; Yang et al., 2010). Usage of the majority medicinal plants for the management for various plant diseases in the activity of antimicrobial effect of phytochemical components (Akinmoladun et al., 2007). Recent investigations the use of plant extracts have innovative move toward to management of phytopathogenic diseases. Plant extracts are regarded as constituents in pest management programmes (Belabid et al., 2010). Compared to the synthetic drugs, antimicrobials of plant source are not associated with many side effects and have massive potential against many infectious pathogens (Barbour et al., 2004). The objective of this work was to evaluate the effect of papaya leaf extracts for controlling wilt disease of tomato caused by $R$. solanacearum under in vitro and in vivo conditions.

\section{Materials and Methods}

\section{Plant material preparation}

Fresh leaves of $C$. papaya were collected from Bangalore, Karnataka and the collected dust free leaves were allowed to dry under shade at room temperature. These dried leaves were mechanically powdered and stored in an airtight container and these powdered materials were used for further analysis.

\section{Preparation of leaves extracts of Carica papaya}

\section{Aqueous extraction}

Ten grams of air dried $C$. papaya leaves powder was extracted in $500 \mathrm{ml}$ of distilled water with slow heat and it was filtered through muslin cloth and centrifuged at 5000 rpm for $15 \mathrm{~min}$. The supernatant was 
collected and filtered through Whatman filter No.1. The extract was autoclaved at $121^{\circ} \mathrm{C}$ with $15 \mathrm{lbs}$ pressure and stored at $4{ }^{\circ} \mathrm{C}$ until further use.

\section{Solvent extraction}

Ten grams of air dried $C$. papaya powder was extracted with $100 \mathrm{ml}$ of solvents like methanol, ethanol, ethyl acetate, hexane and chloroform kept on a rotary shaker for 150 rpm for $24 \mathrm{~h}$ at room temperature. Subsequently, it was filtered through Whatman filter No.1 and centrifuged at 5000 rpm for $15 \mathrm{~min}$. The supernatant was collected and solvent was evaporated to make the final volume one fifth of the original volume and final concentration is $100 \mathrm{mg} / \mathrm{ml}$. It was stored at $4{ }^{\circ} \mathrm{C}$ in airtight bottles for further studies (Pankaj and Purshotam, 2011).

\section{Isolation and identification of $R$. solanacearum}

The wilted tomato and soil samples were collected from the field survey brought to the laboratory. Collected rhizosphere soil and plant materials were plated onto $2,3,5$ Triphenyl tetrazolium chloride (TZC) medium (Kelman, 1954) and incubated at 28 $\pm 2{ }^{\circ} \mathrm{C}$ for $24-48 \mathrm{~h}$. Characterizations of isolated pathogens were carried out by subjected to various biochemical, biovar, physiological, hypersensitive and pathogenicity tests (Narasimha Murthy et al., 2012). The molecular identification based on $16 \mathrm{~S}$ rRNA sequencing for $R$. solanacearum and phylogenetic tree was constructed (Waterman, 1986) and the sequences were deposited to NCBI database.

\section{Preparation of bacterial inoculum}

Inoculum of $R$. solanacearum was prepared by growing cells of the bacterium on CPG broth (1 g Casamino acids, $10 \mathrm{~g}$ peptone, $5 \mathrm{~g}$ glucose in one liter distilled water) for 48 hours at $28{ }^{\circ} \mathrm{C}$ and $150 \mathrm{rpm}$ on rotary shaker (Kleman, 1954). The bacterium cells were centrifuged at $12,000 \mathrm{rpm}$ for $10 \mathrm{~min}$ at $4^{\circ} \mathrm{C}$. The pellet was mixed with distilled water and bacterial suspensions were adjusted to 0.45 at A610 nm using UV- visible spectrophotometer to obtain the concentration approximately $1 \times 10^{8}$ colony forming unit (CFU/ml) (Ran et al., 2005).

\section{Antibacterial activity of extracts against $\boldsymbol{R}$. solanacearum}

Extracts of $C$. papaya antagonistic against $R$. solanacearum by agar well diffusion method (Shrisha et al., 2011). Petriplates containing $20 \mathrm{ml}$ of tryptone soya agar medium, seeded with $100 \mu \mathrm{l}$. solanacearum inoculum, the media was allowed to solidify and wells were prepared in plates with the help of a sterilized cork borer. $100 \mu \mathrm{l}$ of the extracts were introduced into the wells and plates were kept at 2-3 $\mathrm{h}$ for to allow the diffusion of extracts and incubated at $28 \pm 2{ }^{\circ} \mathrm{C}$ for $24-48 \mathrm{~h}$. The pure solvents in equal volume served as negative control and Streptomycin antibiotic disc $(30 \mu \mathrm{g})$ was used as positive control. After incubation the diameter of the zone of inhibition was measured in $\mathrm{mm}$. The experiments were conducted in triplicate under aseptic conditions.

\section{Detection of minimum inhibitory concentration (MIC)}

The micro plate dilution method was used to determine the MIC values for $C$. papaya leaves extracts with antibacterial activity. This test was performed in sterile 96-well microtitre plates. For the evaluation of the active plant extract, diluting the various concentrations ranging from $8 \mu \mathrm{g} / \mathrm{ml}$ to 4096 $\mu \mathrm{g} / \mathrm{ml}$ were prepared and final concentration of $R$. solanacearum was $1 \times 10^{8} \mathrm{cfu} / \mathrm{ml}$. The wells were filled with $50 \mu \mathrm{l}$ of respective 
solvent and $100 \mu \mathrm{l}$ of the C. papaya extracts were added to the wells by serial two fold dilution and streptomycin antibiotic was used as positive control. The plates were incubated at $28 \pm 2{ }^{\circ} \mathrm{C}$ for $24 \mathrm{~h}$, after incubation the MIC was determined as the lowest concentration of plant extracts that exhibited no visible growth of the $R$. solanacearum in the wells by visual reading when compared with the control (Mazzanti et al., 2000).

\section{Effect of $C$. papaya leaf extracts on tomato seed germination and seedling vigor index}

The effect of $C$. papaya leaf extracts on seed germination and vigor index of tomato seedlings were evaluated under laboratory conditions. The germination tests for fresh $R$. solanacearum inoculum and $C$. papaya leaf extracts were carried out according to the paper towel method (ISTA, 2005). The vigor index was calculated by using the formula VI $=($ mean root length + mean shoot length $) \times$ Germination percentage (Abdul Baki and Anderson, 1973). The experiment was conducted with four replicates of hundred seeds each and the entire experiment was repeated thrice.

\section{Effect of $C$. papaya extracts on bacterial wilt incidence in tomato under greenhouse conditions}

This experiment was performed in a greenhouse conditions, with the climatic conditions were maintained an average relative humidity of $80 \%$, in darkness and 30 to $26 \pm 2{ }^{\circ} \mathrm{C}$ temperature regime (Neelu Singh et al., 2012). Pots were filled with sterilized potting soil (soil, sand and coconut pith compost) and $50 \mathrm{ml}$ of sterile water was added to each pot. The soil from each pot was then infested by adding $10 \mathrm{ml}$ of the $R$. solanacearum inoculum solution at $1 \times 10^{8}$ $\mathrm{CFU} / \mathrm{ml}$ to obtain a final estimated population of $2.5 \times 10^{5} \mathrm{CFU} / \mathrm{g}$ of dry soil. Twenty days old tomato seedlings were transplanted five per pot and each plant was watered daily with $30 \mathrm{ml}$ of sterile distilled water. The $R$. solanacearum infested pots were applied by soil drenching with $50 \mathrm{ml}$ of $C$. papaya extracts concentration at $100 \mathrm{mg} / \mathrm{ml}$ and controls received the same amount of sterile water. The wilt susceptible tomato cultivar Arka Meghali was used to assess the wilt incidence. For each treatment, the experiments have been repeated three times. After 30 days of transplanting, wilted tomato plants were sampled for isolation of $R$. solanacearum on modified TZC agar medium. Presumptive colonies of $R$. solanacearum were confirmed by biochemical and molecular characteristics (Deberdt et al., 2012; Narasimha Murthy and Srinivas 2012). The plants including the roots were harvested from the pots and fresh weight, dry weight, mean shoot length, mean root length and disease incidence were measured to determine the effects of $C$. papaya extracts on plant growth. Treated plants were counted and uprooted separately and their weights recorded to measure growth promotion, compared with the untreated control (Lim and Kim 1997). Wilt incidence was recorded using the formula

Percent wilt incidence $=$ Number of infected plants $\times 100$ Total number of plants

\section{Effect of $C$. papaya extracts on bacterial wilt incidence in tomato under field conditions}

The field trials were conducted at the farmer's plot near Chintamani, Karnataka, India during growing seasons. The individual field plots area was $25 \mathrm{~m}^{2}$ containing fourteen rows with 100-120 seedlings per row and distance between rows were $50 \mathrm{~cm}$. The field was maintained based on the tomato growing conditions (Narasimha Murthy et al., 2016). 
The treatment of leaf extracts was carried out like in greenhouse experiments. Wilt symptoms was recorded 7 days after pathogen inoculation. Disease incidence was calculated as described the earlier. Three plots were used as replications for each treatment as well as for the untreated control treatment. Field trials were repeated twice. The number of wilted plants in each treatment including the untreated control was continuously recorded up to 90 days after challenge inoculation and plant height, fresh weight, fruits per plants were calculated. At the time of harvest, ten plants from each replication were harvested to evaluate the total yield of each treatment as tons per hectare $(\mathrm{t} / \mathrm{ha})$.

\section{Results and Discussion}

\section{Isolation and identification of R. solanacearum}

Pink centers with white fluid colonies were selected and 50 isolates of $R$. solanacearum were isolated and identified (Figure 1). Microscopic studies the $R$. solanacearum was Gram negative, rod shaped and characterization of different physiological and biochemical tests. The molecular identification of $R$. solanacearum was confirmed by $16 \mathrm{~S}$ rRNA gene sequencing (Narasimha Murthy et al., 2012).

\section{Antibacterial activity against R. solanacearum}

Antibacterial activity of $C$. papaya extracts against ten highly virulent $R$. solanacearum was conducted. According to the results, $C$. papaya extracts showed the antibacterial activity against $R$. solanacearum isolates (Figure 2). Aqueous and solvent extracts were showed the zone of inhibition range of 9.57 to $11.82 \mathrm{~mm}, \quad 10.27$ to $15.34 \mathrm{~mm}, 6.78$ to $11.33 \mathrm{~mm}, \quad 6.43$ to $10.63 \mathrm{~mm}, 7.33$ to $11.17 \mathrm{~mm}, 6.43$ to $9.57 \mathrm{~mm}$, and 15 to $20 \mathrm{~mm}$ of different solvent extracts that is aqueous, ethanol, ethyl acetate, hexane, chloroform and streptomycin respectively (Table 1).

\section{Minimum Inhibitory Concentration}

Minimum inhibitory concentrations of different $C$. papaya solvent extracts were demonstrated against $R$. solanacearum. The minimum inhibited extracts of Methanol at $512 \mu \mathrm{g} / \mathrm{ml}$, Ethanol at $2048 \mu \mathrm{g} / \mathrm{ml}$, Ethyl acetate at $1024 \mu \mathrm{g} / \mathrm{ml}$, Hexane at $1024 \mu \mathrm{g} / \mathrm{ml}$, Chloroform at $1024 \mu \mathrm{g} / \mathrm{ml}$, Aqueous at 2048 $\mu \mathrm{g} / \mathrm{ml}$ and Streptomycin at $<8 \mu \mathrm{g} / \mathrm{ml}$ (Table 2).

\section{Effect of Carica papaya extract on tomato seed germination and seedling vigor index}

Carica papaya extract treated seeds were increased germination and seedling vigor index as compared to control and decrease the germination with $R$. solanacearum inoculation. The extracts showed extensively higher mean root length, mean shoot length and vigor index with compared to control (Figure 3A; Table 3).

\section{Effect of $C$. papaya extracts on bacterial wilt incidence in tomato under greenhouse conditions}

The reduction in disease incidence on tomato treated with $C$. papaya extracts at $100 \mathrm{mg} / \mathrm{ml}$ concentrations in a growth chamber. The leaf extract treatment increased growth promotion as compared to the control. The treatment increased fresh weight, dry weight, shoots length, root length and reduced the wilt incidence in leaf extract treated seedlings. The disease incidence was decreased around 42.29-52.14\% in plants treated with leaf extracts by soil drench method (Figure 3B; Table 4). The activity of $C$. papaya leaf extracts may be essential in the potential phytochemical compounds and leaf extract percentage, the period of pretreatment 
determine efficiency for wilt control, as revealed in our research.

\section{Effect of $C$. papaya extracts on bacterial wilt incidence in tomato under field conditions}

The efficacy of $C$. papaya leaf extracts were revealed in the tomato fruit yield produced tabulated in Table 5. The control plot was yielded an average of $7.32 \mathrm{t} / \mathrm{ha}$ and $R$. solanacearum treated plot was yielded an average of 1.28 to $1.69 \mathrm{t} / \mathrm{ha}$. Seedlings treated with leaf extract alone plot yielded an average of $8.62 \mathrm{t} / \mathrm{ha}$. As compared to the control plot, C. papaya leaf extract increased the tomato yield by $15.08 \% \quad(1.3 \mathrm{t} / \mathrm{ha})$. Seedlings combined with $R$. solanacearum and leaf extract produces yielded an average of 5.95t/ha. As compared to pathogen treated plot (RS71.28 t/ha), leaf extract treated plot $(8.62 \mathrm{t} / \mathrm{ha})$ was increased yield by $85.15 \%$ (4.26t/ha). Tomato seedlings treated with leaf extract infected plot reduced the wilt incidence by $49.68 \%$ under field conditions as compared to pathogen treated plot $(84.54 \%$ from RS2 infected plot). The C. papaya leaf extracts were found to be active in the management of bacterial wilt of tomato as chemical replacement.

Plants are the cheaper and safer preference sources of antimicrobials (Doughari et al., 2007). The aqueous and solvent extracts investigated phytochemical screening from leaf extracts $C$. papaya was used to study the presence of alkaloids, flavonoids, terpenoids, glycosides, saponins, steroids, phenols, tannins, proteins, anthocyanins, anthocyanins and coumarins. Different phytochemicals have been found to possess a wide range of activities, which may help in protection against phytopathogens. The antibacterial activity of plant extracts on $R$. solanacearum has been studied earlier (Larkin et al., 2007). However, all the phytoconstituents were more in the solvent extraction than the aqueous as indicated by the intensity of the different confirmatory colors. This result can be attested to the work of Sikanda et al., (2013) who also studied like finding and stated the effect of these phytochemical as a good antimicrobial agent on different test pathogens. In the present study, the leaf extracts of $C$. papaya was prepared using aqueous and solvent extraction method. Peter et al., (2014) studied the leaf and root extracts of $C$. papaya, this research indicated that papaya leaves have potential natural antibacterial compounds.

In the ethanol extracts demonstrated a higher activity compared than the other solvents and aqueous extracts in $C$. papaya leaf samples (Uwah et al., 2013). Doughari et al., (2007) stated that the antimicrobial effect of this plant might be due to the bioactive compounds such as the phytochemical constituent present in the plant. The result further showed that the dry sample was effective against both Gram positive and Gram-negative bacteria while the fresh sample was more effective against Gramnegative bacteria (Okunola et al., 2012).

In the antibacterial activity assay, the zone of inhibition at different range from solvent aqueous extracts. Anibijuwon and Udeze (2009) deliberated that the leaf and root of $C$. papaya using water and organic solvents were highest activity against $P$. aeruginosa and our study showed similar results in antibacterial activity against $R$. solanacearum. Antibacterial activity against $R$. solanacearum was found in high from $C$. papaya powder extracts against the bacterial wilt pathogen, MICs of solvent extracts were methanol at $512 \mu \mathrm{g} / \mathrm{ml}$, ethanol at $2048 \mu \mathrm{g} / \mathrm{ml}$, ethyl acetate at $1024 \mu \mathrm{g} / \mathrm{ml}$, hexane at $1024 \mu \mathrm{g} / \mathrm{ml}$, chloroform at $1024 \mu \mathrm{g} / \mathrm{ml}$, aqueous at 2048 $\mu \mathrm{g} / \mathrm{ml}$ and streptomycin at $<8 \mu \mathrm{g} / \mathrm{ml}$. 
Table.1 In vitro antagonistic activity of aqueous and organic extracts of Carica papaya leaves against $R$. solanacearum

\begin{tabular}{|c|c|c|c|c|c|c|c|c|c|c|c|}
\hline \multicolumn{2}{|c|}{ Type of Extracts } & \multicolumn{10}{|c|}{ Zone of inhibition in $\mathbf{~ m m}$} \\
\hline & & RS1 & RS2 & RS3 & RS4 & RS5 & RS6 & RS7 & RS8 & RS9 & RS10 \\
\hline \multirow{5}{*}{$\begin{array}{l}\text { Solvent } \\
\text { Extract }\end{array}$} & Methanol & $12.66 \pm 0.5$ & $15.34 \pm 0.2$ & $11.52 \pm 0.7$ & $10.27 \pm 0.3$ & $13.45 \pm 0.5$ & $12.33 \pm 0.6$ & $13.73 \pm 0.4$ & $13.79 \pm 0.2$ & $12.43 \pm 0.5$ & $11.25 \pm 0.4$ \\
\hline & Ethanol & $8.35 \pm 0.3$ & $9.23 \pm 0.3$ & $9.66 \pm 0.8$ & $11.33 \pm 0.4$ & $8.42 \pm 0.6$ & $10.26 \pm 0.7$ & $9.33 \pm 0.4$ & $8.55 \pm 0.6$ & $10.78 \pm 0.3$ & $11.66 \pm 0.5$ \\
\hline & Ethyl acetate & $8.66 \pm 0.68$ & $9.57 \pm 0.5$ & $9.82 \pm 0.6$ & $7.57 \pm 0.4$ & $9.43 \pm 0.6$ & $10.63 \pm 0.8$ & $9.66 \pm 0.7$ & $7.78 \pm 0.5$ & $8.43 \pm 0.7$ & $10.57 \pm 0.9$ \\
\hline & Hexane & $8.32 \pm 0.2$ & $9.33 \pm 0.6$ & $8.57 \pm 0.8$ & $9.65 \pm 0.7$ & $11.17 \pm 0.9$ & $9.37 \pm 0.5$ & $10.4 \pm 0.6$ & $8.46 \pm 0.7$ & $8.66 \pm 0.5$ & $9.72 \pm 0.5$ \\
\hline & Chloroform & $9.57 \pm 0.5$ & $8.43 \pm 0.7$ & $9.32 \pm 0.5$ & $8.57 \pm 0.4$ & $9.57 \pm 0.5$ & $8.12 \pm 0.8$ & $9.37 \pm 0.8$ & $8.28 \pm 0.5$ & $9.57 \pm 0.7$ & $8.32 \pm 0.8$ \\
\hline \multicolumn{2}{|c|}{ Aqueous Extract } & $7.57 \pm 0.9$ & $6.55 \pm 0.3$ & $6.66 \pm 0.9$ & $5.96 \pm 0.5$ & $7.89 \pm 0.7$ & $7.57 \pm 0.6$ & $6.66 \pm 0.6$ & $7.47 \pm 0.9$ & $6.82 \pm 0.6$ & $7.48 \pm 0.7$ \\
\hline \multicolumn{2}{|c|}{ Streptomycin } & $24.65 \pm 1.2$ & $27.33 \pm 1.6$ & $23.56 \pm 1.9$ & $26.5 \pm 1.3$ & $24.17 \pm 1.7$ & $22.54 \pm 1.1$ & $27.46 \pm 1.6$ & $26.62 \pm 1.9$ & $21.56 \pm 1.5$ & $23.21 \pm 1.8$ \\
\hline \multirow{5}{*}{$\begin{array}{l}\text { Solvent } \\
\text { Control }\end{array}$} & Methanol & $5.45 \pm 0.8$ & $4.47 \pm 0.8$ & $4.57 \pm 0.3$ & $6.22 \pm 0.7$ & $4.66 \pm 0.4$ & $5.67 \pm 0.3$ & $4.56 \pm 0.4$ & $4.76 \pm 0.5$ & $4.33 \pm 0.4$ & $4.57 \pm 0.5$ \\
\hline & Ethanol & $4.56 \pm 0.3$ & $5.66 \pm 0.4$ & $4.21 \pm 0.2$ & $4.56 \pm 0.1$ & $3.45 \pm 0.2$ & $4.66 \pm 0.2$ & $3.45 \pm 0.1$ & $3.43 \pm 0.1$ & $5.57 \pm 0.3$ & $4.33 \pm 0.5$ \\
\hline & Ethyl acetate & $2.33 \pm 0.05$ & $3.66 \pm 0.3$ & $4.66 \pm 0.1$ & $3.57 \pm 0.1$ & $4.78 \pm 0.2$ & $4.33 \pm 0.1$ & $3.31 \pm 0.2$ & $5.66 \pm 0.2$ & $4.57 \pm 0.3$ & $4.12 \pm 0.2$ \\
\hline & Hexane & $3.89 \pm 0.1$ & $4.32 \pm 0.2$ & $5.67 \pm 0.2$ & $2.66 \pm 0.1$ & $2.37 \pm 0.09$ & $2.21 \pm 0.02$ & $3.97 \pm 0.2$ & $4.21 \pm 0.2$ & $4.57 \pm 0.2$ & $4.45 \pm 0.1$ \\
\hline & Chloroform & $4.21 \pm 0.2$ & $3.43 \pm 0.2$ & $4.57 \pm 0.1$ & $3.33 \pm 0.1$ & $2.98 \pm 0.08$ & $2.76 \pm 0.06$ & $3.21 \pm 0.1$ & $3.33 \pm 0.2$ & $3.66 \pm 0.3$ & $3.98 \pm 0.2$ \\
\hline
\end{tabular}

Values are presented as mean \pm Standard errors of triplicate experiments. Mean of three values \pm Standard Deviation. RS- $R$. solanacearum 
Table.2 Minimum inhibitory concentrations of different extracts of Carica papaya against $R$. solanacearum

\begin{tabular}{|c|c|c|c|c|c|c|c|c|c|c|c|}
\hline \multirow[t]{2}{*}{ R. solanacearum } & \multirow[t]{2}{*}{ Extracts } & \multicolumn{7}{|c|}{ Concentration $(\mu \mathrm{g} / \mathrm{ml})$} & \multirow[b]{2}{*}{32} & \multirow[b]{2}{*}{16} & \multirow[b]{2}{*}{8} \\
\hline & & 4096 & 2048 & 1024 & 512 & 256 & 128 & 64 & & & \\
\hline \multirow{6}{*}{ RS1 } & Ethanol & - & - & + & + & + & + & + & + & + & + \\
\hline & Methanol & - & - & + & + & + & + & + & + & + & + \\
\hline & Ethyl acetate & - & + & + & + & + & + & + & + & + & + \\
\hline & Hexane & - & + & + & + & + & + & + & + & + & + \\
\hline & Chloroform & - & - & - & + & + & + & + & + & + & + \\
\hline & Aqueous & - & - & + & + & + & + & + & + & + & + \\
\hline \multirow[t]{6}{*}{ RS2 } & Ethanol & - & - & + & + & + & + & + & + & + & + \\
\hline & Methanol & - & - & - & - & + & + & + & + & + & + \\
\hline & Ethyl acetate & - & + & + & + & + & + & + & + & + & + \\
\hline & Hexane & - & - & - & + & + & + & + & + & + & + \\
\hline & Chloroform & - & - & + & + & + & + & + & + & + & + \\
\hline & Aqueous & - & + & + & + & + & + & + & + & + & + \\
\hline \multirow[t]{6}{*}{ RS3 } & Ethanol & - & + & + & + & + & + & + & + & + & + \\
\hline & Methanol & - & - & + & + & + & + & + & + & + & + \\
\hline & Ethyl acetate & - & + & + & + & + & + & + & + & + & + \\
\hline & Hexane & - & - & + & + & + & + & + & + & + & + \\
\hline & Chloroform & - & - & - & + & + & + & + & + & + & + \\
\hline & Aqueous & + & + & + & + & + & + & + & + & + & + \\
\hline \multirow[t]{6}{*}{ RS4 } & Ethanol & + & + & + & + & + & + & + & + & + & + \\
\hline & Methanol & - & + & + & + & + & + & + & + & + & + \\
\hline & Ethyl acetate & - & - & + & + & + & + & + & + & + & + \\
\hline & Hexane & - & - & + & + & + & + & + & + & + & + \\
\hline & Chloroform & - & - & + & + & + & + & + & + & + & + \\
\hline & Aqueous & - & + & + & + & + & + & + & + & + & + \\
\hline \multirow[t]{6}{*}{ RS5 } & Ethanol & - & - & + & + & + & + & + & + & + & + \\
\hline & Methanol & - & - & - & - & + & + & + & + & + & + \\
\hline & Ethyl acetate & - & - & - & + & + & + & + & + & + & + \\
\hline & Hexane & - & + & + & + & + & + & + & + & + & + \\
\hline & Chloroform & - & - & - & + & + & + & + & + & + & + \\
\hline & Aqueous & - & + & + & + & + & + & + & + & + & + \\
\hline \multirow[t]{6}{*}{ RS6 } & Ethanol & - & - & + & + & + & + & + & + & + & + \\
\hline & Methanol & - & - & + & + & + & + & + & + & + & + \\
\hline & Ethyl acetate & - & - & + & + & + & + & + & + & + & + \\
\hline & Hexane & - & - & - & + & + & + & + & + & + & + \\
\hline & Chloroform & - & - & - & + & + & + & + & + & + & + \\
\hline & Aqueous & - & + & + & + & + & + & + & + & + & + \\
\hline \multirow[t]{6}{*}{ RS7 } & Ethanol & - & - & + & + & + & + & + & + & + & + \\
\hline & Methanol & - & - & - & - & + & + & + & + & + & + \\
\hline & Ethyl acetate & - & - & - & + & + & + & + & + & + & + \\
\hline & Hexane & - & + & + & + & + & + & + & + & + & + \\
\hline & Chloroform & - & + & + & + & + & + & + & + & + & + \\
\hline & Aqueous & - & - & + & + & + & + & + & + & + & + \\
\hline
\end{tabular}




\begin{tabular}{|c|c|c|c|c|c|c|c|c|c|c|c|}
\hline \multirow[t]{6}{*}{ RS8 } & Ethanol & - & - & + & + & + & + & + & + & + & + \\
\hline & Methanol & - & - & - & + & + & + & + & + & + & + \\
\hline & Ethyl acetate & - & - & + & + & + & + & + & + & + & + \\
\hline & Hexane & - & - & + & + & + & + & + & + & + & + \\
\hline & Chloroform & - & - & + & + & + & + & + & + & + & + \\
\hline & Aqueous & - & + & + & + & + & + & + & + & + & + \\
\hline \multirow[t]{6}{*}{ RS9 } & Ethanol & - & - & + & + & + & + & + & + & + & + \\
\hline & Methanol & - & - & - & - & + & + & + & + & + & + \\
\hline & Ethyl acetate & - & - & + & + & + & + & + & + & + & + \\
\hline & Hexane & - & - & - & + & + & + & + & + & + & + \\
\hline & Chloroform & - & - & - & + & + & + & + & + & + & + \\
\hline & Aqueous & - & - & + & + & + & + & + & + & + & + \\
\hline \multirow[t]{7}{*}{ RS10 } & Ethanol & - & + & + & + & + & + & + & + & + & + \\
\hline & Methanol & - & - & - & + & + & + & + & + & + & + \\
\hline & Ethyl acetate & - & - & + & + & + & + & + & + & + & + \\
\hline & Hexane & - & - & + & + & + & + & + & + & + & + \\
\hline & Chloroform & - & + & + & + & + & + & + & + & + & + \\
\hline & Aqueous & - & + & + & + & + & + & + & + & + & + \\
\hline & Streptomycin & - & - & - & - & - & - & - & - & - & - \\
\hline
\end{tabular}

(-) No growth observed'; (+) Growth observed

Table.3 Effect of Carica papaya leaf extract on seed germination and seedling vigor of tomato under laboratory conditions

\begin{tabular}{|c|c|c|c|c|c|c|}
\hline Treatments & $\begin{array}{c}\text { Germination } \\
(\boldsymbol{\%})\end{array}$ & $\begin{array}{c}\text { MRL } \\
(\mathbf{c m})\end{array}$ & MSL (cm) & $\begin{array}{c}\text { Fresh } \\
\text { weight }(\mathbf{g})\end{array}$ & $\begin{array}{c}\text { Dry weight } \\
\text { (g) }\end{array}$ & VI \\
\hline Control & $92.66 \pm 4.56$ & $4.57 \pm 0.21$ & $7.87 \pm 0.57$ & $1.28 \pm 0.066$ & $0.34 \pm 0.054$ & $1152.69 \pm 18.66$ \\
\hline RS1 & $34.0 \pm 0.88$ & $2.73 \pm 0.066$ & $4.63 \pm 0.66$ & $0.45 \pm 0.021$ & $0.19 \pm 0.012$ & $250.24 \pm 5.86$ \\
\hline RS2 & $33.63 \pm 0.57$ & $2.76 \pm 0.074$ & $5.07 \pm 0.33$ & $0.43 \pm 0.14$ & $0.2 \pm 0.021$ & $263.08 \pm 5.98$ \\
\hline RS3 & $35.37 \pm 0.80$ & $2.88 \pm 0.065$ & $4.43 \pm 0.21$ & $0.52 \pm 0.25$ & $0.1 \pm 0.032$ & $258.04 \pm 4.76$ \\
\hline RS4 & $33.66 \pm 0.66$ & $2.78 \pm 0.074$ & $5.86 \pm 0.56$ & $0.48 \pm 0.21$ & $0.1 \pm 0.023$ & $290.30 \pm 4.66$ \\
\hline RS5 & $32.53 \pm 0.93$ & $2.66 \pm 0.082$ & $4.77 \pm 0.78$ & $0.52 \pm 0.16$ & $0.2 \pm 0.036$ & $239.53 \pm 5.57$ \\
\hline RS6 & $35.87 \pm 0.57$ & $2.67 \pm 0.054$ & $4.66 \pm 0.66$ & $0.50 \pm 0.21$ & $0.1 \pm 0.015$ & $262.41 \pm 6.89$ \\
\hline RS7 & $34.65 \pm 0.66$ & $3.12 \pm 0.096$ & $4.94 \pm 0.57$ & $0.51 \pm 0.12$ & $0.2 \pm 0.034$ & $279.27 \pm 5.48$ \\
\hline RS8 & $36.67 \pm 0.87$ & $2.89 \pm 0.091$ & $5.88 \pm 0.68$ & $0.47 \pm 0.16$ & $0.1 \pm 0.046$ & $321.59 \pm 4.66$ \\
\hline RS9 & $34.54 \pm 0.84$ & $2.76 \pm 0.072$ & $4.78 \pm 0.45$ & $0.49 \pm 0.13$ & $0.2 \pm 0.033$ & $260.43 \pm 6.57$ \\
\hline RS10 & $33.33 \pm 0.67$ & $2.83 \pm 0.066$ & $4.96 \pm 0.43$ & $0.48 \pm 0.15$ & $0.2 \pm 0.044$ & $259.64 \pm 5.33$ \\
\hline C. papaya & $94.76 \pm 4.36$ & $6.18 \pm 0.57$ & $8.68 \pm 0.98$ & $1.42 \pm 0.066$ & $0.48 \pm 0.066$ & $1218.61 \pm 19.89$ \\
\hline
\end{tabular}

Values are presented as mean \pm Standard Errors of triplicate experiments. Mean of three values \pm Standard Deviation. MRL - Mean Root Length; MSL - Mean Shoot Length; VI - Vigor Index; RS- R. solanacearum 
Table.4 Effect of Carica papaya leaf extract on bacterial wilt in tomato under greenhouse conditions

\begin{tabular}{|c|c|c|c|c|c|c|}
\hline Treatments & $\begin{array}{c}\text { Plant Height } \\
(\mathbf{c m})\end{array}$ & $\begin{array}{c}\text { MSL } \\
(\mathbf{c m})\end{array}$ & $\begin{array}{c}\text { MRL } \\
(\mathbf{c m})\end{array}$ & $\begin{array}{c}\text { MFW } \\
\mathbf{( g )}\end{array}$ & $\begin{array}{c}\text { Dry } \\
\text { Weight }(\mathbf{g})\end{array}$ & DI (\%) \\
\hline Control & $27.47 \pm 1.57$ & $17.54 \pm 0.78$ & $9.12 \pm 0.78$ & $10.23 \pm 0.66$ & $1.96 \pm 0.048$ & 0.00 \\
\hline RS1 & $16.66 \pm 0.66$ & $7.45 \pm 0.57$ & $5.56 \pm 0.54$ & $4.89 \pm 0.33$ & $0.63 \pm 0.033$ & $79.94 \pm 2.56$ \\
\hline RS2 & $17.12 \pm 0.57$ & $8.56 \pm 0.66$ & $4.45 \pm 0.33$ & $4.45 \pm 0.21$ & $0.58 \pm 0.052$ & $81.14 \pm 4.66$ \\
\hline RS3 & $16.78 \pm 0.89$ & $7.54 \pm 0.43$ & $5.78 \pm 0.42$ & $5.37 \pm 0.32$ & $0.67 \pm 0.066$ & $84.48 \pm 3.57$ \\
\hline RS4 & $17.23 \pm 0.76$ & $8.76 \pm 0.66$ & $4.84 \pm 0.57$ & $4.61 \pm 0.15$ & $0.82 \pm 0.048$ & $78.89 \pm 4.48$ \\
\hline RS5 & $16.63 \pm 0.54$ & $9.23 \pm 0.57$ & $5.63 \pm 0.66$ & $4.78 \pm 0.12$ & $0.91 \pm 0.082$ & $81.76 \pm 3.89$ \\
\hline RS6 & $16.78 \pm 0.66$ & $8.54 \pm 0.89$ & $6.45 \pm 0.23$ & $5.32 \pm 0.48$ & $0.59 \pm 0.067$ & $86.43 \pm 5.66$ \\
\hline RS7 & $16.54 \pm 0.57$ & $7.89 \pm 0.76$ & $5.62 \pm 0.48$ & $5.46 \pm 0.33$ & $0.61 \pm 0.033$ & $87.33 \pm 4.84$ \\
\hline RS8 & $16.89 \pm 0.65$ & $8.67 \pm 0.57$ & $6.58 \pm 0.32$ & $4.84 \pm 0.12$ & $0.65 \pm 0.067$ & $88.78 \pm 6.57$ \\
\hline RS9 & $16.65 \pm 0.57$ & $8.78 \pm 0.48$ & $5.73 \pm 0.40$ & $5.47 \pm 0.33$ & $0.66 \pm 0.084$ & $88.92 \pm 4.89$ \\
\hline RS10 & $17.13 \pm 0.66$ & $8.89 \pm 0.86$ & $5.68 \pm 0.33$ & $5.58 \pm 0.15$ & $0.70 \pm 0.076$ & $79.68 \pm 3.76$ \\
\hline $\begin{array}{c}\text { C.papaya } \\
\text { extract }\end{array}$ & $30.89 \pm 3.47$ & $15.34 \pm 1.33$ & $11.23 \pm 0.89$ & $12.54 \pm 1.12$ & $2.28 \pm 0.066$ & 0.00 \\
\hline RS + C. papaya & $22.66 \pm 2.68$ & $12.48 \pm 1.57$ & $8.68 \pm 0.66$ & $9.55 \pm 0.98$ & $1.36 \pm 0.057$ & $36.78 \pm 2.57$ \\
\hline
\end{tabular}

Values are presented as mean \pm Standard Errors of triplicate experiments. Mean of three values \pm Standard Deviation. MSL- Mean shoot length; MRL- Mean root length; MFW- Mean fresh weight; DI; Disease incidence of tomato plants treated by Carica papaya leaf extract and infested with $R$. solanacearum (RS)

Table.5 Effect of $C$. papaya extracts on tomato plant growth and fruits yield under field conditions

\begin{tabular}{|c|c|c|c|c|c|c|}
\hline Treatments & $\begin{array}{c}\text { Plant } \\
\text { height }(\mathbf{c m})\end{array}$ & $\begin{array}{c}\text { Fresh } \\
\text { weight }(\mathbf{g})\end{array}$ & $\begin{array}{c}\text { Dry weight } \\
\text { (g) }\end{array}$ & $\begin{array}{c}\text { Fruits/ } \\
\text { plant }\end{array}$ & $\begin{array}{c}\text { Yield } \\
\text { t/ha }\end{array}$ & $\begin{array}{c}\text { Wilt } \\
\text { Incidence } \\
(\mathbf{\%})\end{array}$ \\
\hline Control & $69.12 \pm 3.57$ & $589.84 \pm 6.87$ & $38.9 \pm 3.66$ & $28.56 \pm 2.33$ & $7.32 \pm 0.66$ & 0.00 \\
\hline RS1 & $41.62 \pm 1.98$ & $171.63 \pm 4.43$ & $16.63 \pm 1.54$ & $10.75 \pm 0.42$ & $1.46 \pm 0.054$ & $82.32 \pm 3.33$ \\
\hline RS2 & $43.86 \pm 1.66$ & $168.38 \pm 4.57$ & $14.75 \pm 1.33$ & $11.37 \pm 1.57$ & $1.29 \pm 0.067$ & $84.54 \pm 3.57$ \\
\hline RS3 & $38.63 \pm 1.54$ & $165.46 \pm 3.66$ & $17.34 \pm 1.66$ & $10.68 \pm 1.78$ & $1.47 \pm 0.057$ & $81.76 \pm 4.66$ \\
\hline RS4 & $37.54 \pm 1.33$ & $159.93 \pm 4.48$ & $16.33 \pm 1.57$ & $10.94 \pm 1.15$ & $1.69 \pm 0.066$ & $79.68 \pm 2.96$ \\
\hline RS5 & $34.93 \pm 1.12$ & $168.74 \pm 4.57$ & $18.47 \pm 1.89$ & $11.96 \pm 0.66$ & $1.38 \pm 0.064$ & $82.34 \pm 3.53$ \\
\hline RS6 & $39.67 \pm 1.68$ & $164.82 \pm 4.33$ & $19.56 \pm 1.66$ & $9.82 \pm 1.12$ & $1.34 \pm 0.021$ & $83.67 \pm 4.33$ \\
\hline RS7 & $36.83 \pm 1.57$ & $169.96 \pm 3.48$ & $16.73 \pm 1.57$ & $12.23 \pm 1.48$ & $1.28 \pm 0.043$ & $81.66 \pm 3.66$ \\
\hline RS8 & $37.46 \pm 1.67$ & $166.77 \pm 4.63$ & $15.94 \pm 1.48$ & $10.35 \pm 0.54$ & $1.35 \pm 0.68$ & $84.48 \pm 3.57$ \\
\hline RS9 & $35.73 \pm 1.68$ & $170.46 \pm 3.66$ & $17.73 \pm 1.67$ & $12.47 \pm 1.57$ & $1.46 \pm 0.046$ & $82.62 \pm 2.98$ \\
\hline RS10 & $36.69 \pm 3.79$ & $169.83 \pm 3.57$ & $16.85 \pm 1.54$ & $10.78 \pm 0.89$ & $1.37 \pm 0.076$ & $83.54 \pm 3.21$ \\
\hline C.papaya & $92.63 \pm 3.66$ & $712.85 \pm 5.66$ & $44.65 \pm 2.57$ & $39.43 \pm 2.45$ & $8.62 \pm 0.88$ & 0.00 \\
\hline RS + C. & $66.58 \pm 2.89$ & $433.44 \pm 4.68$ & $36.43 \pm 1.66$ & $28.64 \pm 1.89$ & $5.95 \pm 0.24$ & $34.86 \pm 1.57$ \\
papaya & & & & & & \\
\hline
\end{tabular}

Values are presented as mean \pm Standard Errors of triplicate experiments. Mean of three values \pm Standard Deviation 
Fig.1 Colonies of Ralstonia solanacearum from infected tomato fields and Microscopic view of $R$. solanacearum
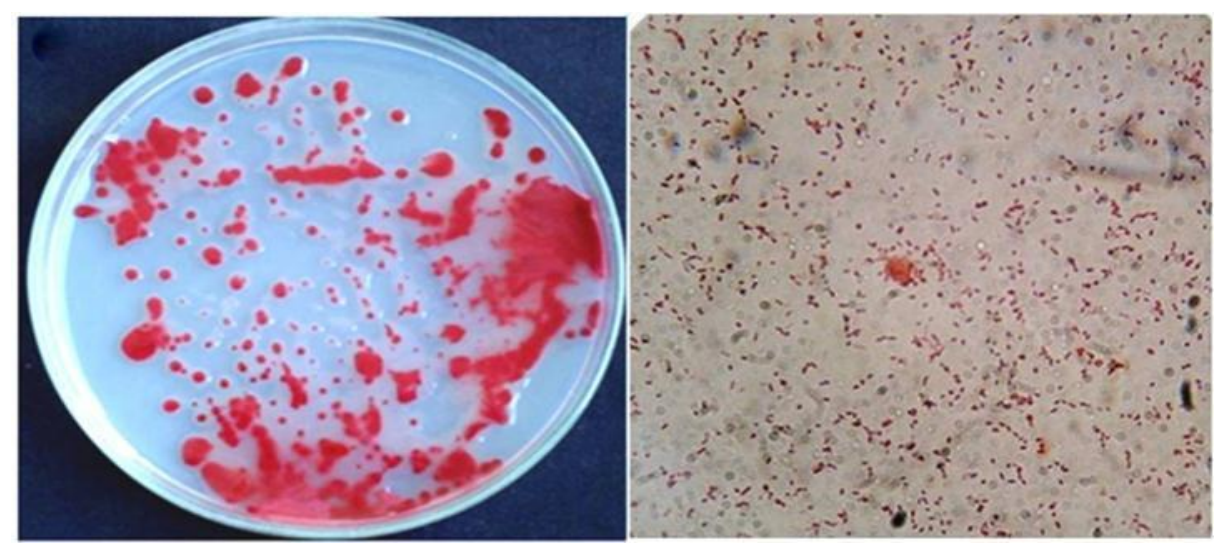

Fig.2 Zone of inhibition of Carica papaya leaf extracts against Ralstonia solanacearum

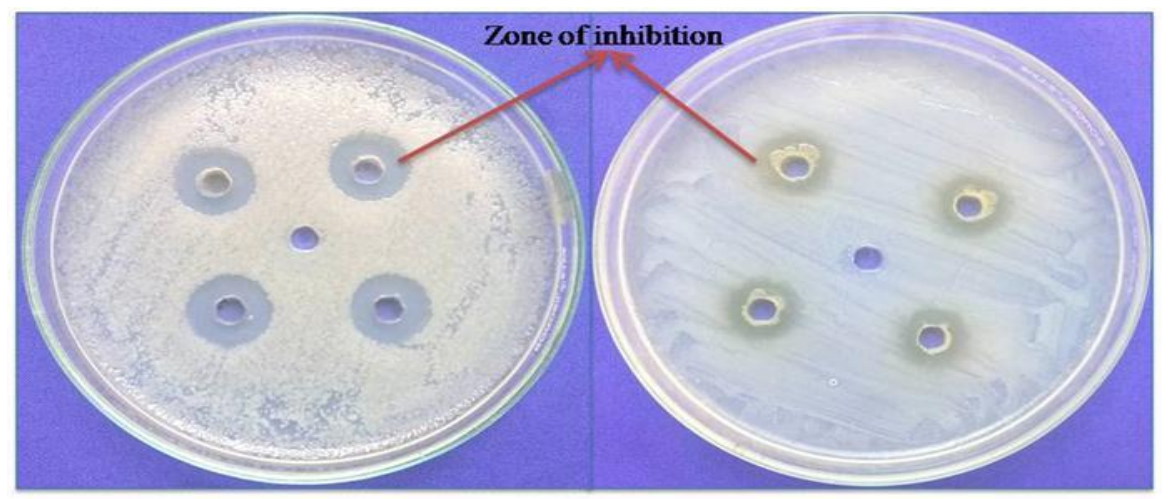

Fig.3A Effect of Carica papaya extract on tomato seed germination and seedling vigor index.

Seed germination of tomato seedlings a and b- C. papaya leaf extract treatment, c and d-

Controls and e- Pathogen treated seedlings Fig.3B Effect of $C$. papaya extracts on bacterial wilt incidence in tomato under greenhouse conditions. a $-C$. papaya extracts treated, b- $R$. solanacearum treated and c- $C$. papaya extracts and $R$. solanacearum treated
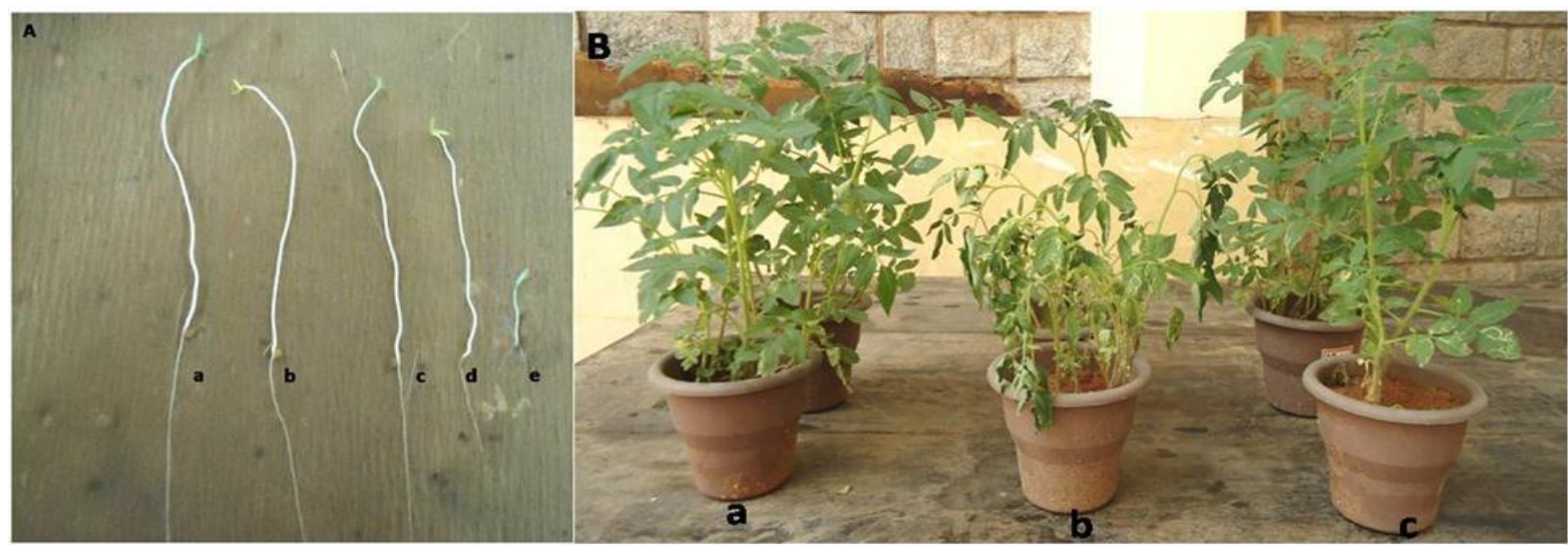
The results were evident the use of $C$. papaya leaf powder extracts has a potential to substitute the antibiotics to control the infection (Sumathi and Gowthami 2014). Thus, $C$. papaya could become promising natural antimicrobial agents with potential applications in agriculture for controlling the bacterial wilt of tomato. However, if plant extracts are to be used for control of plant pathogens in agriculture. The greenhouse and field trial experiments designated that tomato seedling with leaf extracts resulted in a significant decrease in bacterial wilt disease. These outcomes were similar to previous research on the part of plant extracts in the control of bacterial disease.

In our study revealed the antibacterial activity of solvent extracts of $C$. papaya against $R$. solanacearum, the causal agent of bacterial wilt. It may be concluded from this study that C. papaya leaf extracts were in vitro and in vivo against phytopathogens. The antibacterial activity of $C$. papaya extracts were found much better than the broad spectrum antibiotic. Plants extracts are originate to be an actual reservoir for the bioactive compounds and can offer valuable sources for the detection of natural pesticides (Akhtar et al., 1997).

Further isolation and purification of the extracts are necessary to conclude the bioactive components responsible for their activity. It is important that research should continue to isolate and purify the bioactive components from $C$. papaya leaves responsible for the control of pathogens. The bioactive components in the extract of the $C$. papaya could be commercially exploited for the decrease of the wilt diseases in tomato plants. Although our results support the idea that $C$. papaya extracts are candidate for control of bacterial plant pathogens in vitro and in vivo conditions.

\section{Acknowledgements}

The authors gratefully acknowledge the UGCBSR (Basic Scientific Research) Meritorious Fellowship, University Grants Commission, Government of India and New Delhi. The authors also wish to thank the Chairman, Department of Microbiology and Biotechnology, Bangalore University, Bangalore, India, for providing the facilities for this research.

\section{References}

Abdul Baki AA and Anderson JD. 1973. Vigor determination in soybean seed by multiple criteria. Crop Science 13:630-633.

Ahmed AS, Sanchez CP and Candela ME. 2000. Evaluation of induction of systemic resistance in pepper plants (Capsicum annuum) to Phytophthora capsici using Trichoderma harzianum and its relation with capsidol accumulation. European Journal of Plant Pathology 106(9):817-824.

Akhtar MA, Rahber-Bhatti MH and Aslam M. 1997. Antibacterial activity of plant diffusate against Xanthomonas campestris pv. Citri. International Journal of Pest Management 43 (2): 149-153.

Akinmoladun AC, Ibukun EO, Afor E and Obuotor EM. 2007. Pytochemical constituents and antioxidant activity of extract from the leaves of the Ocimum graticcimum. Scientific Research and Essays 2 (5): 163-166.

Aliye N, Fininsa C and Hiskias Y. 2008. Evaluation of rhizosphere bacterial antagonists for their potential to bioprotect potato (Solanum tuberosum) against bacterial wilt (Ralstonia solanacearum). Biological Control 47 (3): 282-288.

Anibijuwono I and Udeze AO. 2009. 
Antimicrobial activity of papaya on some pathogenic organisms of clinical origin from south-western Nigeria. Ethnobotanical Leaflets 13(7): 850 864.

Barbour EK, Al Sharif M, Sagherian VK, Habre AN, Talhouk RS and Talhouk SN. 2004. Screening of selected indigenous plants of Lebanon for antimicrobial activity. Journal of Ethnopharmacology 93(1): 1-7.

Belabid, Lakhdar, Simoussa, Leila B and Bassam. 2010. Effect of some plant extracts on the population of Fusarium oxysporium f. sp. lentis, the causal organism of lentil wilt. Advances in Environmental Biology 4(1): 95-100.

Deberdt P, Perrin B, Coranson-Beaudu R, Duyck PF and Wicker E. 2012. Effect of Allium fistulosum extract on Ralstonia solanacearum populations and tomato bacterial wilt. Plant Disease 96: 687-692.

Doughari JH, Elmahmood AM and Manzara S. 2007. Studies on the antibacterial activity of root extracts of Carica papaya Linn. African Journal of Microbiology Research 14: 37-41.

El-Ariqi SNS, El-Moflehi M, El-Arbara K, El-Kobati A and El-Shaari A. 2005. Antibacterial activity of extracts from Withania somnifera and Aloe vera aginst Ralstonia solanacearum in potato. Arab Journal of Plant Protection 23: 95-99.

Elphinstone JG. 2005. The current bacterial wilt situation: a global overview. In: Allen C, Prior P and Hayward AC editors. Bacterial wilt disease and the Ralstonia solanacearum species complex. American Phytopathological Society. Press; St Paul, MN. pp. 9-28.

Hayward AC. 1991. Biology and epidemiology of bacterial wilt caused by Pseudomonas solanacearum. Annual Review of Phytopathology
29(1): 65-87.

Ji P, Momol MT, Olson SM, Pradhanang PM and Jones JB. 2005. Evolution of Thymol as biofunmigant for control of bacterial wilt of tomato under field conditions. Plant Disease 89: 497 500.

Jones JB, Woltz SS, Jones JP and Portier KL. 1991. Population dynamics of Xanthomonas campestris pv. vesicatoria on tomato leaflets treated with copper bactericides. Phytopathology 81: 714-719.

Kelman A. 1954. The relationship of pathogenicity in Pseudomonas solanacearum to colony appearance on a tetrazolium medium. Phytopathology 44: 693-695.

Kishun R. 1987. Loss in yield of tomato due to bacterial wilt caused by Pseudomonas solanacearum. Indian Phytopathology 40 (2): 152-155.

Larkin RP and Griffins TS. 2007. Control of soilborne potato diseases using Brassica green manures. Crop Protection 26(7): 1067-1077.

Lim H and Kim S. 1997. Role of siderophores in biocontrol of Fusarium solani and enhanced growth response of bean by Pseudomonas fluorescens GL20. Journal of Microbiology and Biotechnology 7 (1): 13-20.

Mazzanti G, Mascellino NT, Pattinelli L, Coluccia D, Manganario $\mathrm{M}$ and Saso L. 2000. Antimicrobial investigation of semi purified fractions of Ginkgo biloba leaves. Journal of Ethnopharmacology Lausanne 71(12): 83-88.

Narasimha MK, Malini M, Fazilath U, Soumya KK, Chandra NS, Ramachandrappa NSR and Srinivas C. 2016. Lactic acid bacteria mediated induction of defense enzymes to enhance the resistance in tomato against Ralstonia solanacearum 
causing bacterial wilt. Scientia Horticulturae 207: 183-192.

Narasimha Murthy K and Srinivas C. 2012. In vitro screening of bioantagonistic agents and plant extracts to control bacterial wilt (Ralstonia solanacearum) of tomato (Lycopersicon esculentum). Journal of Agricultural Technology 8(3): 999 1015.

NCCLS-National Committee for Clinical Laboratory Standards. 1997. Methods for dilution antimicrobial susceptibility tests for bacteria that grow aerobically. Approved Standards M7-A4, Wayne Pa.

Neelu S and Siddiqui A. 2012. Inoculation of Tomato with Ralstonia solanacearum, Xanthomonas campestris and Meloidogyne javanica. International Journal of Vegetable Science18:7886.

Okunola AA, Muyideen HT, Chinedu AP, Jegede T and Abia H. 2012. Comparative studies on antimicrobial properties of extracts of fresh and dried leaves of Carica papaya on clinical and fungi isolates. Advances in Applied Science Research 3(5): 3107-3114.

Pankaj G and Purshotam K. 2011. In vitro evaluation of antibacterial activity of various crude leaf extracts of Indian Sacred plant, Ocimum sanctum L. Br. Research Journal of Microbiology 1(3): 70-78.

Parekh J, Nair R and Chanda S. 2005. Preliminary screening of some folkloric plants from Western India for potential antimicrobial activity. Indian Journal of Pharmacology 37: 408409.

Perez C, Pauli M and Bazerque P. 1990. An antibiotic assay by the agar-well diffusion method. Acta Bio Medicine Experiment 15:113-115.
Peter JK, Kumar Y, Pandey P and Masih H 2014. Antibacterial activity of seed and leaf extract of Carica Papaya var. Pusa dwarf Linn 9(2): 29-37.

Pradhanang PM, Ji P, Momol MT, Olson SM, Mayfield JL and Jones JB. 2005. Application of acibenzolar-S-methyl enhances host resistance in tomato against Ralstonia solanacearum. Plant Disease 89(9): 989-993.

Ran LX, Liu CY, Wu GJ, van Loon LC and Bakker PAHM. 2005. Suppression of bacterial wilt in Eucalyptus europhylla by Fluorescent Pseudomonas spp. Chinese Journal of Biological Control 32: 111-120.

Shivpuri A, Sharma OP and Thamaria S. 1997. Fungitoxic properties of plant extracts against pathogen fungi. Journal of Mycology and Plant Pathology 27 (1): 29 -31.

Shrisha DL, Raveesha KA and Nagabhushan. 2011. Bioprospecting of selected medicinal plants for antibacterial activity against some pathogenic bacteria. Journal of Medicinal Plants Research 5 (17): 4087-4093.

Sikandar KS, Tasveer ZB, Kanwal N, Syed AG and Shahama UK. 2013. Qualitative phytochemical screening and antifungal activity of Carica papaya leaf extract against human and plant pathogenic fungi. International Research Journal of Pharmacy 4(7): 83-86.

Singh D, Yadav DK, Chaudhary G, Rana VS and Sharma RK. 2016. Potential of Bacillus amyloliquefaciens for biocontrol of bacterial wilt of tomato incited by Ralstonia solanacearum. Journal of Plant Pathology and Microbiology 7:327.

Sumathi R and Gowthami M. 2014. Phytochemical analysis and in- vitro Antimicrobial activity of aqueous and solvent extracts of Carica papaya 
against clinical pathogens. International journal of advanced research in biological sciences 1(1): 73-77.

Uwah AF, Otitoju O, Ndem JI and Peter AI. 2013. Chemical composition and antimicrobial activities of adventitious root sap of Musanga cecropioides. Der Pharmacia Lettre 5(2): 13-16.

Waterman MS. 1986. Multiple sequence alignment by consensus. Nucleic Acids Research 14(22): 9095-9102.
Williamson L, Nakaho K, Hudelson B and Allen C. 2002. Ralstonia solanacearum race 3, biovar 2 strains isolated from geranium are pathogenic on potato. Plant Disease 86(9): 987991.

Yang X, Ma X, Yang L, Yu D, Qian Y and Ni H. 2010. Efficacy of Rheum officinale liquid formulation on cucumber powdery mildew. Biological Control 522:167-173.

\section{How to cite this article:}

Narasimha Murthy, K., K. Soumya, C. Srinivas and Niranjana, S.R. 2019. Evaluation of Carica papaya Leaf Extracts for their Efficacy on Control of Bacterial Wilt of Tomato caused by Ralstonia solanacearum. Int.J.Curr.Microbiol.App.Sci. 8(03): 366-380.

doi: https://doi.org/10.20546/ijcmas.2019.803.046 